Dept. of Food Hygiene,

Animal Health Research Institute, Alexandria Branch.

\title{
HYGIENIC STATUS OF IMPORTED FROZEN BEEF IN ALEXANDRIA MARKETS
}

(With 4 Tables)

\author{
By \\ AMAL F.A. MANSOUR and OLA A.M. BASHA* \\ * Dept. of Bacteriology, Animal Health Research Institute, Alexandria Branch
}

(Received at 16/3/2009)

\section{الحالة الصحية للحوم البقرى المستوردة المجمدة فى أسواق الإسكندرية}

\section{أمال فههى على منصور ، علا عبل العزبيز محد باشا}

أجرى هذا البحث بجمع عدد خمسون عينة عشوائية من اللحوم البقرية المجمدة المشفاة

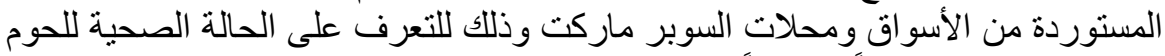

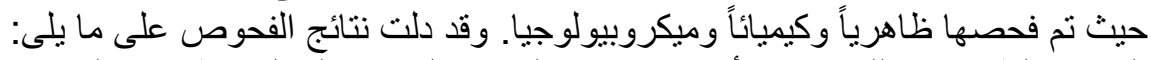

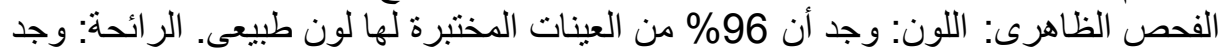

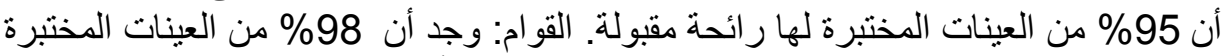
لها قو ام طبيعى ولا توجد عليها عفن. الفحص الكيميائى: الأس الهيدروجينى للعينات التهات المختبرة

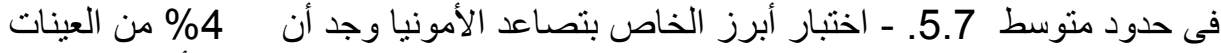

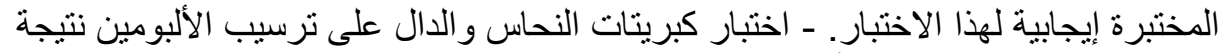
لتحلل وتكسير البروتين وجد أن 8 8 من العينات كانت إيجابية. المركبات النيتروجينية

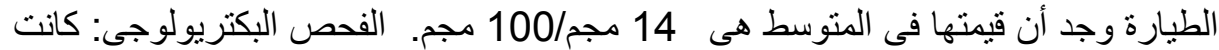
متوسط أعداد الميكروبات المحبة للبرودة، الميكروبات الهوائية، الميكروبات المعوية المبة،

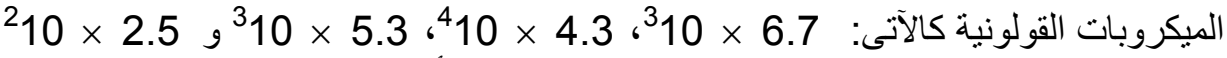

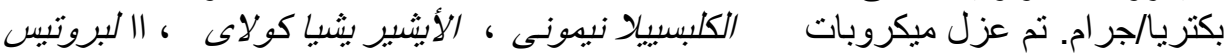

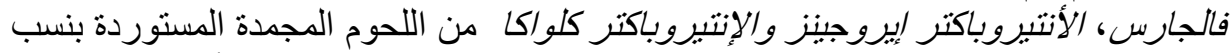

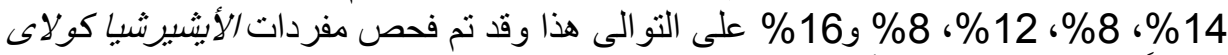
فحصاً سبرولوجيا و ووجد أن العترات تنتمى إلى

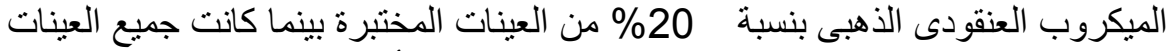

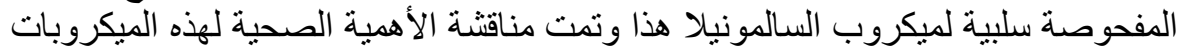

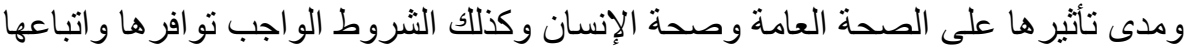
للمحافظة على سلامة اللحوم المجمدة المستوردة. 
A total of 50 random samples of imported frozen boneless beef meat of different cuts were collected from different markets of Alexandria. The samples were transferred directly to the laboratory where they were examined organoleptically, chemically and microbiologically for determination of its hygienic status. The organoleptic examination revealed that the normal colour was detected in $96 \%$ of the examined samples. Acceptable odour was detected in $95 \%$ of the examined samples and normal consistency was detected in $98 \%$ of the examined samples. The chemical examination indicated that the $\mathrm{pH}$ and total volatile nitrogen (T.V.N.) were within the permissible limits. The results of Eber's and copper sulphate tests were positive in 4 and $8 \%$ respectively. Bacteriological examination of the all samples revealed that the total psychrophilic bacterial count, total aerobic plate count, total enterobacteriaceae count, and total coliform count were $6.7 \times 10^{3}$, $4.3 \times 10^{4}, 5.3 \times 10^{3}$, and $2.5 \times 10^{2} \mathrm{cfu} /$ gram respectively. Klebsiella pneumoniae, Escherichia coli, proteus valgaris, Enterobacter aeorgenes and Enterobacter cloaca were isolated from the examined frozen meat samples at an incidence of 14, 8, 12, 8 and 16\% respectively. The incidence of Staphylococcus aurues was $20 \%$, on the other hand, Salmonella microorganisms could not be isolated from any of the examined samples. Escherichia coli strains were serotyped as $\mathrm{O}_{55}, \mathrm{O}_{111}$, $\mathrm{O}_{114}$ and $\mathrm{O}_{119}$. The public health hazard of these microorganisms as well as the recommended measures to improve quality status of imported frozen beef were discussed.

Key words: Beef, bacterial count, $p H, T V B-N$

\section{INTRODUCTION}

Food-borne infections are an important public health concern worldwide. According to reports of the World Health Organization and the Centers for Disease Control and Prevention, every year a large number of peoples are affected by food borne diseases due to consumption of contaminated beef (Busani et al., 2005).

Meat constitutes the most important items of human food because of its palatability and high nutritional value, at the same time, meat is prone to contamination from the hands and clothes of staff, from knives and other equipment during deboning and carcass breaking processes (Gill et al., 2001). 
In Egypt, as a result of increase demand for meat, frozen boneless beef was extensively imported from different countries. Meat is relative perishable therefore meat should be refrigerated as quick as possible, following slaughter to minimize undesirable changes (Smith et al., 1983). To prolong shelf life of meat, deep freezing should be adapted to retard the microbial growth (ICMSF., 1978). Koburger (1981) and Mansour (1986) stated that bacteria Gram-positive and Gramnegative could survive the frozen storage of meat and when the condition become favourable they begin to multiply. So, meat may constitute a public health hazard due to the presence of spoilage microorganisms responsible for objectionable changes or pathogens leading to either food infection of intoxication (Hannien, 1980, FAO/WHO, 1983). Meat is unfit for human consumption when surface count are more than $10 \% \mathrm{~cm}^{2}$ and interior counts of $10^{5} / \mathrm{gm}$ (Hyytiainen et al., 1975; Mates, 1983). pH markedly influence protein changes during freezing an storage (Gracey, 1986) and total volatile nitrogen could be used as an indication of decomposition by bacteria and protein breakdown during storage (Pearson, 1968). The higher value of T.V.N could be attributed to high bacterial counts and hence high protein destruction (Fahmy et al., 1981).

According to the Egyptian Standard Specification of frozen meat (1552/1991) when T.V.N value reached more than $20 \mathrm{mg} / 100 \mathrm{~g}$, meat will be rejected. The aim of this study was to evaluate the hygienic status of imported frozen meat at Alexandria markets.

\section{MATERIALS AND METHODS}

\section{A- Samples:}

Fifty random samples of imported frozen boneless beef of different cuts were collected from different markets in Alexandria, they were directly transferred to the laboratory in an ice box under complete aseptic condition, where they were examined organoleptically, chemically and bacteriologically.

\section{B- Organoleptic examination}

The samples were examined for, colour, odour, consistency and slime formation according to Gracy (1986), Ockerman and Hansen (1988) and Miller (1994).

\section{C- Chemical examination}

The samples were examined for: 
a- Detection of ammonia in spoiled meat using Eber's test (Mousa, 1991), after Gerhardt and Dam (1979).

b- Determination of $\mathrm{pH}$ value according to ISO (1974).

c- Determination of total volatile nitrogen according to FAO (1992).

d- Detection of precipitation of albumenous material from decomposed meat using copper sulphate test. (Mousa, 1991).

\section{D- Bacteriological examination}

The samples were subjected to bacteriological examination through determination of:

a- Total psychrophilic count according to ICMSF (1978).

b- Aerobic plate count by spreading technique according to European Union Regulation (2001).

c- Enterobacteriaceae count according to European Union Regulation (2001).

d- Enumeration of coliform bacterial count according to FAO (1992).

\section{E- Detection of some food-borne pathogens:}

a- Isolation and identification of Staphylococcus aureus according to Bennett and Lancette (2001).

b- Isolation and identification of Enteropathogenic E-coli according to Health Protection Agency (2003). Seriological identification using diagnostic sera, Biotec E. coli (1999).

\section{RESULTS}

A- Organoleptic examination of frozen imported meat samples showed relatively acceptable colour,odour, consistency and without slime formation.

B- Chemical examination:

the result of chemical examination were summarized in Table (1) A and $\mathrm{B}$.

Table (1) A: Results of Eber's and Copper sulphate tests $(n=50)$

\begin{tabular}{|l|c|c|}
\hline \multicolumn{1}{|c|}{ Test } & +ve samples & $\%$ \\
\hline Eber's & 2 & 4 \\
\hline Copper sulphate & 4 & 8 \\
\hline
\end{tabular}

Table (1) B: Results of PH and Total Volatile Nitrogen (T. V. N.) mg / $100 \mathrm{~g}$ sample. 


\begin{tabular}{|l|c|}
\hline \multicolumn{1}{|c|}{ Test } & Result \\
\hline $\mathrm{pH}$ & $5.8 \pm 0.25$ \\
\hline TVB-N & $14 \mathrm{mg} / 100 \mathrm{~g} \pm 0.7$ \\
\hline
\end{tabular}

Where: \pm stander error

Table (2): Mean values of bacterial counts for the examined imported frozen beef meat samples $(n=50)$.

\begin{tabular}{|l|c|}
\hline \multicolumn{1}{|c|}{ Microbial count } & Mean vlues \\
\hline Total psychrophilic count & $6.7 \times 10^{3}$ \\
\hline Total aerobic plate count & $4.3 \times 10^{4}$ \\
\hline Total Enterobacteiaceae count & $5.3 \times 10^{3}$ \\
\hline Total Coliform count & $2.5 \times 10^{2}$ \\
\hline
\end{tabular}

Table (3): Incidence of the recovered microorganisms from the examined samples $(n=50)$.

\begin{tabular}{|l|c|c|}
\hline \multicolumn{1}{|c|}{ Isolated organisms } & No. of +ve samples & $\%$ \\
\hline Klebsiella pneumoniae & 7 & 14 \\
\hline Escherichia coli & 4 & 8 \\
\hline Proteus vulgaris & 6 & 12 \\
\hline Enterobacter aerogenes & 4 & 8 \\
\hline Enterobacter cloaca & 8 & 16 \\
\hline Staph. Aureus & 10 & 20 \\
\hline
\end{tabular}

Table (4): Serotyping of Escherichia coli.

\begin{tabular}{|l|c|c|c|c|c|c|}
\hline Serotypes & $\mathrm{O}_{55}$ & $\mathrm{O}_{128}$ & $\mathrm{O}_{111}$ & $\mathrm{O}_{114}$ & $\mathrm{O}_{119}$ & $\mathrm{O}_{142}$ \\
\hline Number & 1 & - & 1 & 1 & 1 & - \\
\hline
\end{tabular}

\section{DISCUSSION}

All the examined samples were relatively acceptable in odour, colour and consistency and without slime formation. The same results were reported by EL-Tabei (1992) who found that all the examined imported frozen meat had normal colour and odour. The consistency of meat was mainly affected by the percentages of fat, moisture, connective tissue and texture (Roushdy, 1979). 
The mean values of the $\mathrm{pH}$ and TVB-N of the imported frozen beef meat samples were 5.8 and $14 \mathrm{mg} / 100 \mathrm{~g}$ which were within the permissible limits according to the Egyptian Standards (2001).

Ammonia is a by product of microbial metabolism and mainly derived from various desaminase reaction. The onset of spoilage was accompanied by a rapid rise in ammonia concentration (Schmitt and Schmidt-Lorenz, 1992). The result presented in Table (1) revealed that $4 \%$ of the examined imported frozen meat samples were positive for ammonia as detected by the Ebers test. The quantity of ammonia has been used to indicate spoilage of meat (Gika, 1980).

From Table (1), 8\% of the examined imported frozen meat samples by copper sulphate test were positive for the presence of albuminous materials which indicated meat decomposition.

The results presented in Table (2) showed that the mean values of psychrophilic count, aerobic plate count, Enterobacteriaceae and coliform counts of imported frozen beef samples were $6.7 \times 10^{3}, 4.3 \times$ $10^{4}, 5.3 \times 10^{3}$ and $2.5 \times 10^{2} / \mathrm{gm}$ respectively. Hafiz (1986) reported that the mean value of the total psychrophilic count/g was $1.1 \times 10^{7}$ which was higher than that obtained in this study. The occurrence of psychrophilic microorganisms is usually attributed to microbial contamination during slaughtering process (Newton et al., 1978). The obtained results of total aerobic counts were nearly similar to that reported by El-Ataal (1987). Refai et al. (1991) found that the mean total aerobic bacterial count $(\mathrm{CFU} / \mathrm{g})$ of the examined frozen meat samples was $2.7 \times 10^{6}$. The total aerobic bacterial count was the most reliable index for detecting the sanitary condition for proper storage of food products (Levin, 1961).

The Enterobacteriaceae count in the obtained study was lower than that reported by Refaie et al. (1991). It is evident from Table (2) that the mean coliforms count per gram of $2.5 \times 10^{2}$.

Nearly similar results were reported by Varkonti (1980) while higher results were reported by Goda et al. (1981), they found that the mean total coliform count was $15 \times 10^{2} \mathrm{CFU} / \mathrm{g}$. Presence of Coliforms suggested mostly faecal contamination and points of potentially severe hazard (Eribo and Jay, 1985).

Table (3) illustrates that klebsiella pneumoniae, Escherichia coli, Proteus vulgaris, Enterobacter aerogenes and Enterobacter cloaca were isolated from imported frozen meat samples at an incidence of 14, 8, 12, 8 and $16 \%$ respectively. Nearly higher incidence was reported by Hafez (1986) who isolated Klebsiella pneumoniae, Escherichia coli, Proteus 
valgaris, Enterobacter aerogenes, Enterobacter cloaca, Citrobacter freundi and Proteus mirabilis from frozen meat in an incidence of 14, $23,26,18,17,28$ and $14 \%$ respectively.

Salmonella could not be isolated from any of the examined samples. This was in agreement with the Egyptian Standard Specification of frozen meat $(1552,1991)$ that stated that frozen meat should be free from Salmonella. The results obtained in Table (3) revealed that the incidence of Staph. aureus in the examined imported frozen meat samples was $20 \%$ which was higher than that reported by Phillips et al. (2001) who found that the incidence of Staph. aureus was 17.5\%. The high levels of Staph. aureus growth indicate poor hygiene of the meat handlers during the processing stage as well as lack of sterilization of utensils (Thatcher and Clark, 1978). Staphylococcus aureus has been implicated in food poisoning and food intoxication, besides it may at time assumes a pathogenic role, so strict hygienic measures should be adapted in meat to ensure a maximum safety to consumer. (WHO, 1957). The results of serological identification for serotyping of Escherichia coli isolated from the examined imported frozen beef as shown in Table (4) revealed that $E$. coli was serotyped as one strain of each $\mathrm{O}_{55}, \mathrm{O}_{111}, \mathrm{O}_{114}$, and $\mathrm{O}_{119}$. The obtained results are nearly similar serotyping as recorded by Mostafa (1993). George (2004) reported that E. coli serotypes $\mathrm{O}_{55}$ and $\mathrm{O}_{111}$ were implicated as the causative agents for nursery school outbreaks in London in 1940s. They also added that $\mathrm{O}_{111}, \mathrm{O}_{119}, \mathrm{O}_{128}$ and $\mathrm{O}_{142}$ serotypes were isolated from infected infants in North America and Europe during the 1950 and up to 1970 years. These outbreaks had a high attack rate with high mortality rate exceed $50 \%$ in infants.

\section{REFERENCES}

Bennett; R.W. and Lancette, G.A. (2001): Staphylococcus aureus, chapter 12, Rev. In FDA Bacteriological Analytical Manual $8^{\text {th }}$ ed., Rev. AOAC International, Gaithersburg. M.D.

Biotec (1999): Bacterial typing antisera. Biotec Laboratories Ltd. Ipswich. Suffolk. M.K.

Busani, L.; Cigliano, A. and Tailoli, E. (2005): Prevalence of Salmonella enterica and Listeria monocytogenes contamination in foods of animal origin in Italy. J Food Prot. 68, (8): 1729-1733.

Egyptian Standard Specification of Frozen Meat No. 1552(1991): Egyptian Organization for Standarization and Quality Control. 
Egyptian Standards (2001): Chilled Meats. Number 3602. Egyptian Organization for Standardization and Quality Control.

El-Attal, S. (1987): Microbiological quality of frozen meat. M.V.Sc. Thesis, Meat Hygiene, Fac. Vet. Med., Cairo Univ.

El-Tabei, M.H. (1992): Microbiological evaluation of imported frozen meat. M.V.SC., Meat Hygiene, Fac. Vet. Med., Suez Canal Univ.

Eribo, E. and Jay, J.M. (1985): Incidence of Acinetobacter species and other Gram negative, oxidase negative bacteria in fresh and spoiled ground beef. Appl. Env. Microbiol, 49(1): 256-257.

European Union Communities Commission (2001): Commission decision of 8 June 2001laying down rules for the regular checks on the general hygiene Document 2001/471/EEC. Off. J. Eur communities 21-6-2001 L 165: 48-53.

Fahmy, A.A.; Nor El-Dean, M.R. and Mostafa, M.M. (1981): Effect of frozen storage on some physical and chemical changes of meat and separated drip. Monoufeia J. Agric. Res. 4: 235.

FAO (1992): Manual of food quality control, microbiological analysis. Part 4. P. 131. Food and Agricultural Organization of United Nation. Rome.

FAO/WHO (1983): WHO Surveillance Program for Control of Food borne Infection and Intoxication in Europe. Inst. Vet. Med. $2^{\text {nd }}$ Ed Report., Berlin (West).

George, C. (2004): The incidence, growth and survival of diarrhoeagenic Escherichia coli in South Africa meat products. Master science (Food microbiology) university of the free state. South Africa.

Gerhardt, V. and Dam- 9 Quang, T. (1979): Methods for determination of ammonia in meat and meat products. Fleischwirtschaft, 59(7): 946-948.

Gika, J.; Ingr, I. and Palasek, J. (1980): Beurteilung des frischergrades Von ZU Halbfertigerzeugnissen bestimmtem fleisch fleischwirtschaft, 60: 118-122.

Gill, C.; Bryant, J. and Badoni, M. (2001): Effect of hot water pasteurizing treatments on the microbiological condition of manufacturing beef used for hamburger patty manufacture. J.Food Micro., 63: 243-256.

Goda, E.F.M.; Wassef, N.A.; Saad, Z. and El-Sawah, H. (1981): Microbiol contamination of important frozen meat. J. Egypt. Vet. Med. Assoc. 41(4): 89-97.

Gracy, J.F. (1986): Meat Hygiene, $7^{\text {th }}$ ed. Bailliere Tindall, London. 
Hafez, A.E. (1986): Studies on the sanitary condition of frozen meat markets in Sharkia province. Ph. D.V.Sc. Thesis, Meat Hygiene. Fac. Vet. Med. Zagazig Univ.

Hannien, M.L. (1980): E. coli, Yersinia enterocolitica and Compylobacetr fetus spp. Jejuni Causing food borne disease. A review. Soumen Elanile Akarileti, 86: 175.

HPA2 (Health protection Agency) (2003): standard method for food products. Direct enumeration of Escherichia coli standard method F20. Available at:htt:// www.hpo.org.UK/srmd/diveslsu/sops- does/ fsops/ f20i1.3.pdf. Accessed 26 January 2004.

Hyytianinen, M.; Ponjia, M.S. and Niskanen, A. (1975): Bacteriological methods for examination and quality assessment of meat. Fleischwritschaft, 55: 49.

ICMSF (1974): Microorganisms in food. 2- sampling for microbiological analysis, principles and specific application.

ICMSF: International Commission on Microbiological Specification for Food. (1978): Microorganisms in food. Their significance and method of Enumeration, $2^{\text {nd }}$ Ed. Univ. of Toronto. Press, Toronto and Buffalo's Canada.

ISO (1974): International Standard 2917-1974. Meat and meat products; measurement of $\mathrm{pH}$ (reference method). International standard organization.

Koburger, J.A. (1981): Effect of frozen storage on fungi in foods. J. Food Prot., 44 (4): 300-301.

Levine, M.M. (1961): Facts and fancies of bacterial incidence in standard for water and food. Fd. Technol., 15: 22-24.

Mansour, N.K. (1986): Wum vorkommen von schimmelpilzer der gattung cladosporium link ex-fries Auf schaffleish. Vet. Med. Diss., Munchen.

Mates, A. (1983): Microbiological survey of frozen ground meat and proposed standard. J. Food. Prot. 46 (2): 87-89.

Miller, R.K. (1994): Quality characteristics. In: Kinsman, K. M.; Kotula, A. W. and Breidenstein, B.C. (Eds) muscle food. Chapman and Hall, New York. London.

Mostafa, M. (1993): Bacteriological studies on certain Gram-negative food-borne pathogens. Ph. D. thesis. Military Institute of Health and Epidemiology, Military Medical Acadmy.

Mousa, M.M.I. (1991): Practical meat hygiene. Text book for undergraduate students, Fac. Vet. Med. Alex. Univ. P. 22-26. 
Newton, K.G; Harrison, J.C.L. and Wauters, A.M. (1978): Sources of psychrotrophic bacteria on meat at the abattoir. J. Appl. Bacteriol. 54: 75-82.

Ocherman, H.W, and Hansen, C.L. (1988): Animal by-product processing. PP 29-30 Ellis Horwood ltd, Chickester, England.

Pearson, D. (1968): Application of chemical methods for assessment of beef quality. 2- method related to protein breakdown. J. Fd. Sc. Agric. 19: 366.

Phillips, D.; Summer, J. and Alexander, F. (2001): Microbiological quality of Asterian beef. J. Food Prot. 64 (5): 692-696.

Refaie, R.S.; Seham, M.A.; Thabet, A.R. and El-Timawy, A.M. (1991): Microbiological quality of frozen meat in Assiut. Assiut. Vet. Med. J. 24 (48): 198-163

Roushdy, S.A. (1979): Studies on market minced meat, M.V.Sc., meet Hygiene, Fac. Vet. Med., Cairo Univ.

Schmitt, R.E. and Schmitt-Lorenz, W. (1992): Formation of ammonia and amines during microbial spoilage of refrigerated broilers. Lebensmittel wissenschaft und technologie, 25: 6-10.

Smith, G.C.; Savell, J.W.; Stiffer, O.M.; Johnson, D.D. and Anderzant, C.V. (1983): Weight loss and quality characteristics of frozen versus chilled beef livers and hearts. J. Fd. Sc., 48: 1726.

Thatcher, F.S. and Clark, D.S. (1978): Microorganisms in foods, their significance and methods of enumeration. $1^{\text {st }}$ Ed. Univ. Toronto., Cited after Koburger and Wahlguists. J. Food. Prot., 42 (12): 956.

Varkonti, I.J. (1980): Microbiological quality of quick frozen meat rolls Hutoiper, 27: 105.

WHO (1957): Meat hygiene monograph series. No. 33. 